Article

\title{
Partial Characterization of an Enzymatic Extract from Bentong Ginger (Zingiber officinale var. Bentong)
}

Ahmad Nafi, ${ }^{1,2, \dagger}$, Foo Hooi Ling ${ }^{3, \dagger}$, Jamilah Bakar ${ }^{1, \dagger}$ and Hasanah M. Ghazali ${ }^{1, \dagger, *}$

1 Faculty of Food Science and Technology, Universiti Putra Malaysia, 43400 UPM Serdang, Selangor DE, Malaysia; E-Mails: ama_nafi@yahoo.com (A.N.); jamilah@upm.edu.my (J.B.)

2 Faculty of Agricultural Technology, University of Jember, of J1 Kalimantan 37 Tegalboto Jember 68121 East Java, Indonesia

3 Faculty of Biotechnology and Biomolecular Sciences, Universiti Putra Malaysia, 43400 UPM Serdang, Selangor Darul Ehsan, Malaysia; E-Mail: hlfoo@upm.edu.my

$\dagger$ These authors contributed equally to this work.

* Author to whom correspondence should be addressed; E-Mail: hasanah@upm.edu.my; Tel.: +603-8946-8345; Fax: +603-8942-3552.

Received: 4 July 2014; in revised form: 30 July 2014 / Accepted: 7 August 2014/

Published: 15 August 2014

Abstract: Extraction of protease from a local ginger rhizome (Zingiber officinale var. Bentong) was carried out. The effect of extraction $\mathrm{pH}(6.4,6.8,7.0,7.2,7.6,8.0,8.4$, and $8.8)$ and stabilizers $(0.2 \%$ ascorbic acid, $0.2 \%$ ascorbic acid and $5 \mathrm{mM}$ EDTA, or $10 \mathrm{mM}$ cysteine and $5 \mathrm{mM}$ EDTA) on protease activity during extraction was examined. $\mathrm{pH} 7.0$ potassium phosphate buffer and $10 \mathrm{mM}$ cysteine in combination with $5 \mathrm{mM}$ EDTA as stabilizer were found to be the most effective conditions. The extraction procedure yielded $0.73 \%$ of Bentong ginger protease (BGP) with a specific activity of $24.8 \pm 0.2 \mathrm{U} / \mathrm{mg}$ protein. Inhibitory tests with some protease inhibitors classified the enzyme as a cysteine protease. The protease showed optimum activity at $60{ }^{\circ} \mathrm{C}$ and $\mathrm{pH} 6-8$, respectively. The enzyme was completely inhibited by heavy metal cations such as $\mathrm{Cu}^{2+}$, and $\mathrm{Hg}^{2+}$. SDS stimulated the activity of enzyme, while emulsifiers (Tween 80 and Tween 20) slightly reduced its activity. The kinetic analysis showed that the protease has $K_{m}$ and $\mathrm{V}_{\max }$ values of $0.21 \mathrm{mg} \mathrm{mL}^{-1}$ and $34.48 \mathrm{mg} \mathrm{mL}^{-1} \mathrm{~min}^{-1}$, respectively. The dried enzyme retained its activity for 22 months when stored at $-20^{\circ} \mathrm{C}$. 
Keywords: stabilizer; biochemical properties; storage stability

\section{Introduction}

Ginger, known botanically as Zingiber officinale Roscoe, has its origin in South Asia but has spread to many other regions of the world, where it is is used in foods or other applications. In ancient times, ginger was used as medicine in India, China and Europe. Today, ginger is one of the most important and widely used spices in the world [1]. Ginger is also used in pharmacy due to the presence in the rhizome of the phenolic substances gingerol and shagaol [2] which are reported to have anti-cancer [3] and antioxidant activities [2]. Since 1973, ginger was identified as one of the sources of protease with an irrefutable proteolytic activity. Currently, the sale of protease constitutes the largest enzyme trade in the global market and is forecasted to reach $\$ 3.74$ billion in 2015 [4]. In order to fulfill market needs, researchers have explored proteases from animal [5], plant [6] and microbial [7] sources. Among the plant proteases, bromelain from pineapple (Ananas comosus) and papain from papaya (Carica papaya) are the main industrial proteases, but they account for only $8 \%$ of the market share [8]. Hence, researchers keep searching for new sources of plant protease to meet industrial needs.

Ginger protease (GP) or zingibain, which was first reported as a new source of protease in 1973, exhibits remarkable proteolytic activity [9]. GP is very active meat tenderizer against collagen and other connective tissue proteins [9-12]. Good milk clotting activity is also attributed to GP [6] and, therefore, it is used in the preparation of ginger milk curd in the south of China.

A previous study regarding characterization of protease extracted from common ginger (Zingiber officinale Roscoe) showed an optimum activity at $60^{\circ} \mathrm{C}$ with a broad $\mathrm{pH}$ range of 6 to 8 . The enzyme, is considered as a cysteine protease due to its inhibition by NEM and $\mathrm{Hg}^{2+}$ and $\mathrm{Cu}^{2+}$ and the fact it retains its activity in the presence of monocations except $\mathrm{Li}^{+}$and some detergents [13]. The protease in ginger rhizome could be extracted using buffer or organic solvents such as ethanol and acetone. Sodium phosphate buffer $\mathrm{pH} 7$ and Tris- $\mathrm{HCl}$ buffer $\mathrm{pH} 8$ have been used to extract the protease $[8,12]$. Cysteine enhanced the thermostability of a ginger protease while ethylenediamine tetraacetic acid (EDTA) was not an effective stabilizer [8]. Ascorbic acid was also reported to prevent oxidation from occurring during GP extraction hence improving its stability [6,8]. In order to enhance the stability of GP, a combination of those stabilizers needs to be studied.

Malaysia, one of the ginger-producing countries in Southeast Asia, produced 9.017 metric tons of ginger rhizomes in 2012 [14]. One of the exotic ginger varieties grown in Malaysia is the Bentong ginger or halia Bentong (Zingiber officinale Var. Bentong) [15]. This variety is cultivated only at Bentong, a highland in Malaysia. Bentong ginger shows a different phenolic substances profile [16] and anti-oxidative activity [17] in comparison with other Malaysian gingers. In order to develop a possible value-added usage for this ginger in comparison with common ginger, a study was conducted to examine the properties of BGP following extraction and partial purification. 


\section{Results and Discussion}

\subsection{Extraction of Ginger Protease (BGP) and Effect of Stabilizers}

The $\mathrm{pH}$ and the presence or absence of a stabilizer played a significant role during the extraction of protease from ginger rhizomes. The activity of the enzyme was significantly higher $(p \leq 0.05)$ when extracted at neutral $\mathrm{pH}$ (Figure 1) compared to acidic or alkaline $\mathrm{pH}$. This result is similar to that of a previous study which successfully produced protease from ginger using phosphate buffer at $\mathrm{pH} 7$ [12,13].

Figure 1. Effect of extraction $\mathrm{pH}$ on activity of Bentong ginger protease. Different letters indicate significant differences at $p \leq 0.05$.

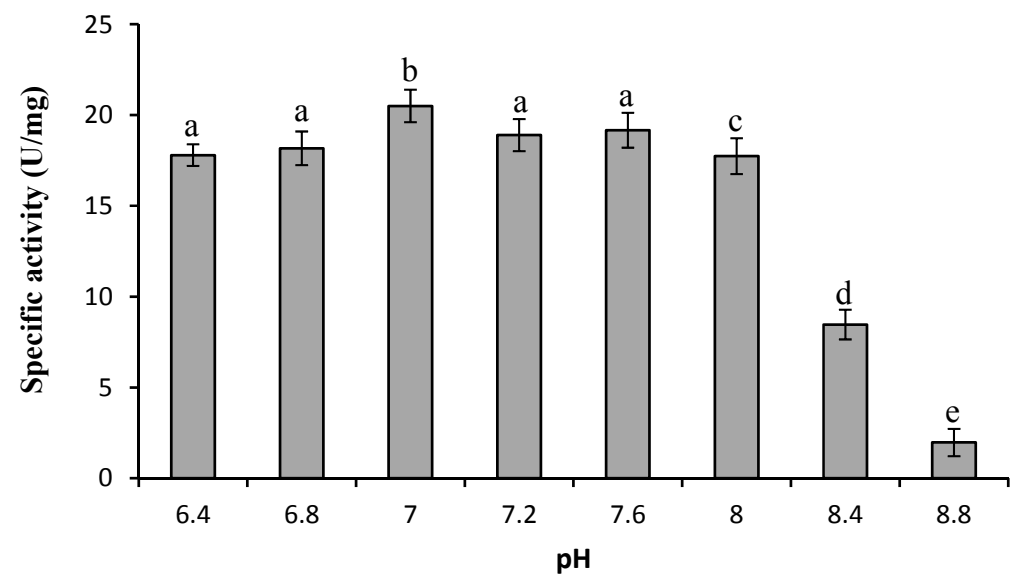

The activity of BGP during extraction was stabilized greatly by addition of EDTA (Table 1) and $10 \mathrm{mM}$ cysteine. Ascorbic acid $(0.2 \% \mathrm{w} / \mathrm{v})$ in combination with EDTA showed higher stabilization effect than ascorbic acid alone for a duration of up to 4 days.

Table 1. Effect of extraction stabilizers on activity of Bentong ginger protease. Means in the same row with the same superscript capital letter are not significantly different $(p \leq 0.05)$. Means in the same column with the same superscript small letter are not significantly different $(p \leq 0.05)$.

\begin{tabular}{ccccc}
\hline \multirow{2}{*}{$\begin{array}{c}\text { Day of } \\
\text { Storage }\end{array}$} & \multicolumn{3}{c}{ Enzyme Activity (unit/mL) of Different Stabilizers at 4 ${ }^{\circ} \mathbf{C}$} \\
\cline { 2 - 5 } & Control $^{*}$ & $\begin{array}{c}\mathbf{0 . 2 \%} \text { Ascorbic } \\
\text { Acid }\end{array}$ & $\begin{array}{c}\mathbf{0 . 2 \%} \text { Ascorbic Acid } \\
+\mathbf{5 ~ m M ~ E D T A ~}\end{array}$ & $\begin{array}{c}\mathbf{1 0} \text { mM Cysteine } \\
+\mathbf{5} \text { mM EDTA }\end{array}$ \\
\hline 0 & $11.7 \pm 0.2^{\mathrm{Aa}}$ & $25.9 \pm 0.4^{\mathrm{Ba}}$ & $30.7^{\mathrm{Ba}} \pm 0.5^{\mathrm{Ca}}$ & $32.6 \pm 0.4^{\mathrm{Ca}}$ \\
1 & $5.0 \pm 0.2^{\mathrm{Ab}}$ & $23.8 \pm 0.2^{\mathrm{Ba}}$ & $29.0 \pm 0.1^{\mathrm{Cb}}$ & $31.9 \pm 0.5^{\mathrm{Da}}$ \\
2 & $1.6 \pm 0.2^{\mathrm{Ac}}$ & $20.8 \pm 0.4^{\mathrm{Bb}}$ & $28.8^{\mathrm{Cb}} \pm 0.3^{\mathrm{Cb}}$ & $31.4 \pm 0.2^{\mathrm{Db}}$ \\
3 & $0.7 \pm 0.2^{\mathrm{Ac}}$ & $19.4 \pm 0.3^{\mathrm{Bc}}$ & $28.4 \pm 0.3^{\mathrm{Cb}}$ & $30.9 \pm 0.4^{\mathrm{Db}}$ \\
4 & $0.3 \pm 0.1^{\mathrm{Ac}}$ & $17.4 \pm 0.3^{\mathrm{Bd}}$ & $27.1 \pm 0.5^{\mathrm{Cc}}$ & $29.3 \pm 0.2^{\mathrm{Dc}}$ \\
\hline
\end{tabular}

This result is similar to that of a previous study which successfully produced protease from common ginger [13]. Cysteine is an anti-autolysis agent effective for protecting the stability of protease during extraction [8]. EDTA improved the stability of the protease activity of both crude extract (Figure 2) and dried BGP. In solution, EDTA chelates the metal ions that could lead to inactivation of the enzyme by attacking the sulfhydryl group in the locus of cysteine protease. EDTA 
also could protect the enzyme from oxidation occurring during extraction [18]. Without any stabilizers, the activity of crude ginger proteases decreased drastically during extraction and storage.

Figure 2. Effect of inhibitors on the activity of Bentong ginger protease. $O$-PT: $o$-phenanthroline; PMSF: Phenylmethylsulfonyl fluoride; EDTA: Ethylenediamine tetra-acetic acid; NEM: $N$-ethylmaleimide. Different superscripts indicate significant difference $(p \leq 0.05)$.

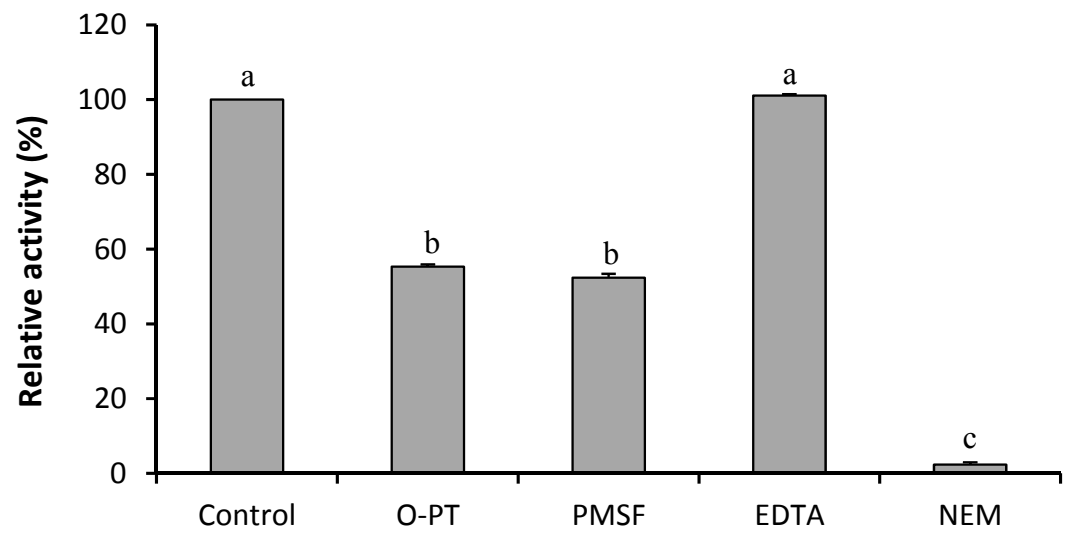

Type of protease inhibitors

The method used for the production of lyophilized BGP yielded $0.73 \%$ (w/w of fresh ginger rhizome) of dry BGP with a specific activity of $24.8 \pm 0.2 \mathrm{Unit} / \mathrm{mg}$ protein. The current method used in this study is comparable with those employed in the previous studies. A protease extraction using acetone followed by $60 \%(\mathrm{w} / \mathrm{v})$ ammonium sulfate precipitation to extract and concentrate ginger protease from China obtained a yield of $0.6 \%(\mathrm{w} / \mathrm{v})$ protease [19]. However, BGP's yield and specific activity was lower than that of common ginger protease which has yield of $0.94 \%$ (w/w of fresh weight) with a specific activity of $27.6 \pm 0.1 \mathrm{Unit} / \mathrm{mg}$ [16]. The different varieties of ginger rhizome (common and Bentong) used probably caused that differences in yield and specific activity.

\subsection{Characterization of Ginger Protease}

\subsubsection{Determination of Protease Type}

The activity of the BGP under study was found to be greatly inhibited by NEM (Figure 2), therefore, this protease is most likely a cysteine protease. By using leupeptin, iodoacetic acid and E-64 (trans-1-epoxysuccinylleucylamido-(4-guanidino)-butane), $\mathrm{Su}$ et al. [6] also concluded that ginger protease was a cysteine protease. However, the ginger protease was significantly inhibited by PMSF and $o$-phenanthroline (Figure 2). This phenomenon is similar to cysteine protease extracted from common ginger [13] and garlic, whose activity was also inhibited by PMSF [20]. Furthermore, PMSF and $o$-phenanthroline also reduced the activity of a cysteine extracted from capsules of caper (Capparis spinosa) [21]. The reduction of protease activity was most likely to be attributed to the occurrence of PMSF bound to serine and $o$-phenanthroline complexed with alanine, phenylalanine or tryptophan residues on the non-active side of BGP, thereby reducing the affinity of the substrate with the 
enzyme and subsequently reducing the enzyme activity. In addition, Frey and Hegeman [22] reported that no reagents are exactly specific to a certain nucleophilic group, but also can react with other groups.

\subsubsection{Optimum Temperature}

The optimum temperature of BGP was $60{ }^{\circ} \mathrm{C}$ (Figure 3). The result obtained is similar to the findings of $[13,20]$ who reported that ginger protease exhibited broad optimal proteolytic activity from 40 to $60{ }^{\circ} \mathrm{C}$ and lost its activity when the temperature increased to $70{ }^{\circ} \mathrm{C}$. The loss in activity at $70{ }^{\circ} \mathrm{C}$ was $64 \%$ in the present study due to denaturation of the enzyme. With its high optimum temperature, BGP shows potential for food industry applications such as milk coagulation [23] and as a meat tenderizing agent [11].

Figure 3. Effect of temperature on activity of Bentong ginger protease.

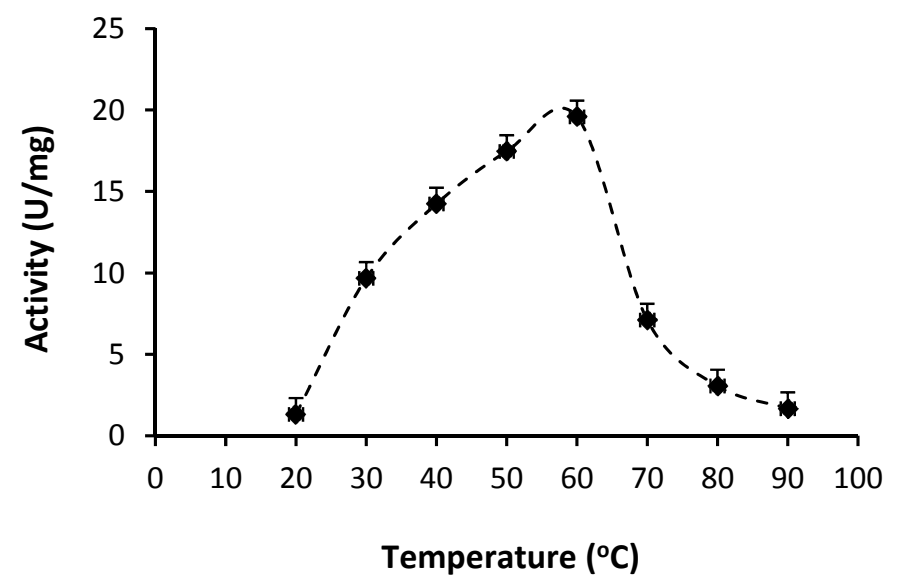

\subsubsection{Optimum $\mathrm{pH}$}

BGP was found to have an optimum $\mathrm{pH}$ that ranged from 6.0 to 8.0 (Figure 4). A similar result was obtained in a previous study [13]. Other plant proteases, such as procerain, a protease extracted from Callotropis procera, showed an optimal hydrolysis of azoalbumin at $\mathrm{pH}$ values ranging from 7.0 to 9.0 [24].

Figure 4. Effect of $\mathrm{pH}$ on activity of Bentong ginger protease.

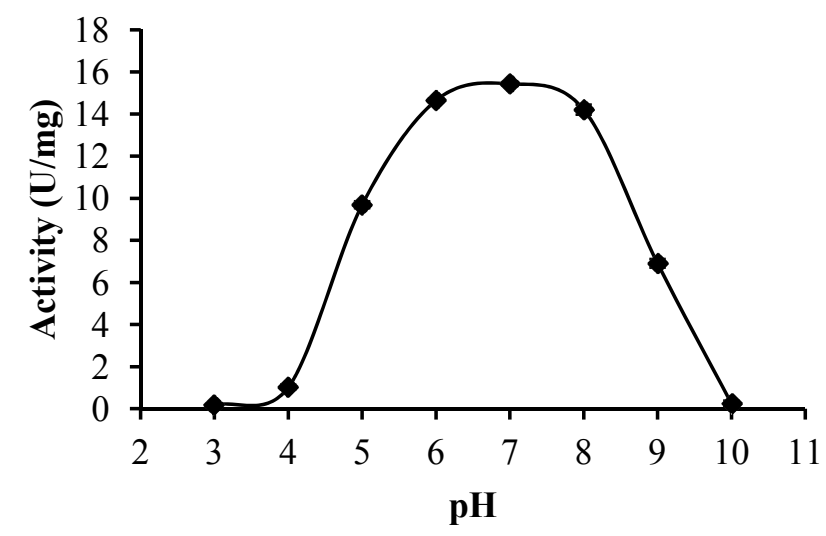


A protease extracted from kesinai (Streblus asper) leaves showed optimum activity on $\mathrm{pH} 7.5$ [25]. The protease of crude preparation was detected in this research displayed a broad optimum $\mathrm{pH}$ range, hence warranting broad application in various food processing uses.

\subsubsection{Effect of Cations and Detergents}

The thiol-blocking heavy metal cations of $\mathrm{Cu}^{2+}$ and $\mathrm{Hg}^{2+}$ were found to significantly inhibit the proteolytic activity of BGP ( $p \leq 0.05$, Table 2$)$. In comparison, monovalent cations have no significant effect on BGP. However, $\mathrm{Li}^{+}$and divalent cations such as $\mathrm{Co}^{2+}$ and $\mathrm{Zn}^{2+}$ demonstrate moderate inhibition of $50.6 \%, 59.5 \%$ and $33.5 \%$, respectively. The reduction in BGP protease activity was most likely due to the sulfhydryl group in the active site of BGP being affected by those metal cations and causing the inactivation of cysteine protease. A similar result was reported by Demir et al. [21], where metal cations such as $\mathrm{Hg}^{2+}$ and $\mathrm{Cu}^{2+}$ caused substantial inhibition of a cysteine protease, capparin, extracted from capsules of caper (Capparis spinosa). These result also showed agreement with previous study on effect of cation on proteolytic activity of common ginger protease [13].

Table 2. Effect of cations on the activity of Bentong ginger protease. The same letter indicates not significantly different at $p \leq 0.05$.

\begin{tabular}{cc}
\hline Cations & Relative Activity (\%) \\
\hline Control & $100.0 \pm 0.0^{\mathrm{a}}$ \\
$\mathrm{K}^{+}$ & $96.3 \pm 3.4^{\mathrm{a}}$ \\
$\mathrm{Na}^{+}$ & $100.7 \pm 1.1^{\mathrm{a}}$ \\
$\mathrm{Li}^{+}$ & $50.6 \pm 3.2^{\mathrm{b}}$ \\
$\mathrm{Mg}^{2+}$ & $89.0 \pm 1.3^{\mathrm{c}}$ \\
$\mathrm{Ba}^{2+}$ & $79.9 \pm 2.2^{\mathrm{d}}$ \\
$\mathrm{Ca}^{2+}$ & $76.4 \pm 0.6^{\mathrm{e}}$ \\
$\mathrm{Co}^{2+}$ & $59.5 \pm 2.7^{\mathrm{f}}$ \\
$\mathrm{Zn}^{2+}$ & $33.5 \pm 2.2^{\mathrm{g}}$ \\
$\mathrm{Cu}^{2+}$ & $4.7 \pm 2.6^{\mathrm{h}}$ \\
$\mathrm{Hg}^{2+}$ & $0.3 \pm 0.1^{\mathrm{i}}$ \\
$\mathrm{Al}^{3+}$ & $92.6 \pm 3.4^{\mathrm{c}}$ \\
\hline
\end{tabular}

Figure 5. Lineweaver-Burk plot for the effect of substrate concentration on activity of the ginger protease.

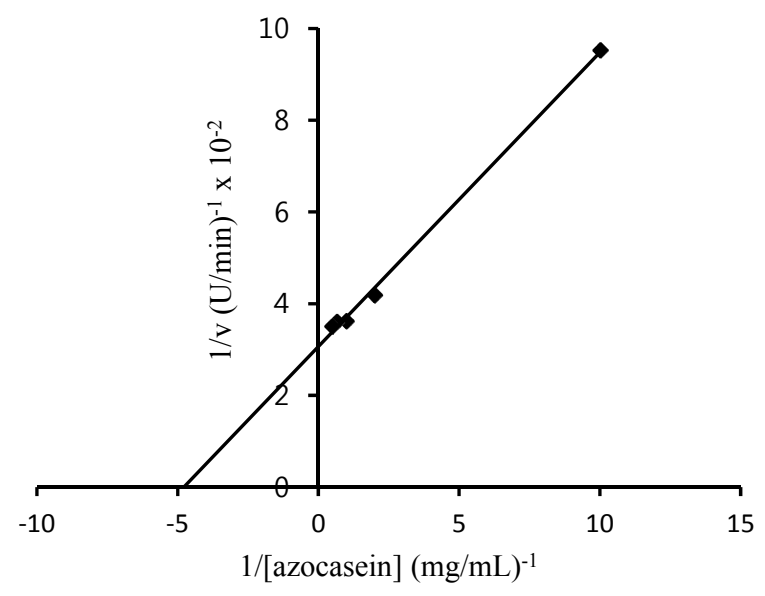


The effects of detergents tested in this experiment are shown in Figure 5. Interestingly, SDS at $0.25 \mathrm{mM}$ enhanced the activity of BGP by $27.4 \%$. The effect of detergents on proteolytic activity of BGP was similar that seen with common ginger protease [13]. A similar result was also reported by Demir et al. [21], where $0.1 \mathrm{mM}$ SDS stimulated the activity of capparin by $47 \%$, but a higher concentration of SDS at either 1 or $10 \mathrm{mM}$ would completely inhibit its proteolytic activity. SDS at low concentrations could mask the intrinsic charge of protein [26]. Being negatively charged, SDS tends to attract the hydrogen atom of the sulfhydryl group of cysteine. The ionized cysteine at the active site of BGP possibly facilitates the binding reaction of substrate-enzyme and, therefore, contributes to the increment in the activity of BGP by $27 \%$. Triton X-100 as a nonionic detergent has no inhibitory effect while an emulsifier detergent, such as Tween 20 and Tween 80, significantly reduced $(p \leq 0.05)$ the proteolytic activity of BGP (Figure 6). The negative effect of these emulsifiers most probably caused the change of the enzyme's conformation when the hydrophobic amino acid residues were disturbed by the nonpolar sites of the emulsifiers.

Figure 6. Effect of detergents on activity of ginger protease. Different superscripts indicate a significant difference $(p \leq 0.05)$.

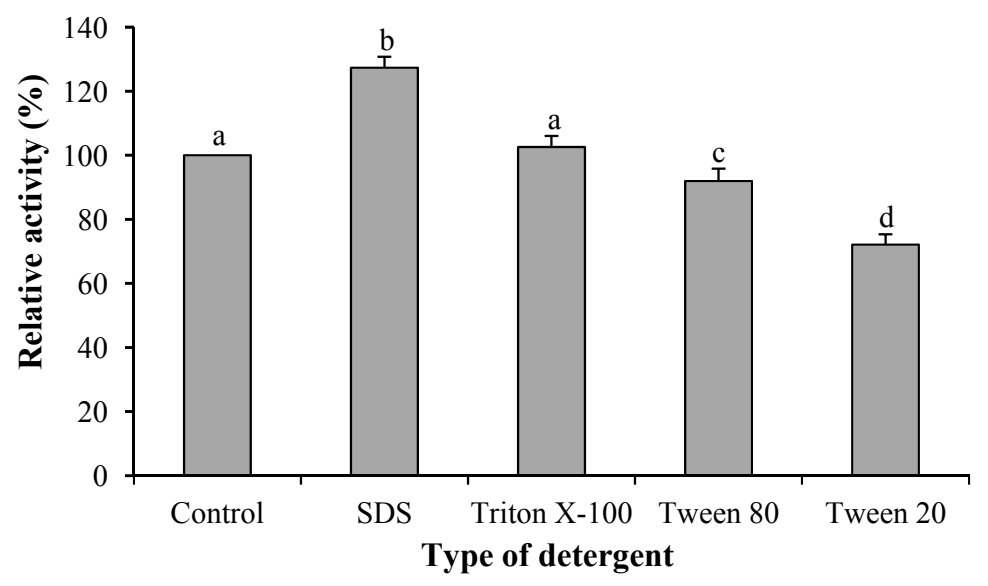

\subsection{5. $K_{m}$ and $\mathrm{V}_{\max }$ Value of BGP}

The calculated $K_{m}$ and $\mathrm{V}_{\max }$ values of BGP were $0.21 \mathrm{mg} \mathrm{mL} L^{-1}$ and $34.48 \mathrm{mg} \mathrm{mL}^{-1} \mathrm{~min}^{-1}$, respectively. Kinetics analysis of common ginger protease showed that it has lower $K_{m}$ and higher $\mathrm{V}_{\max }$ values of $0.18 \mathrm{mg} \mathrm{mL}^{-1}$ and $\mathrm{V}_{\max }$ of $35.74 \mathrm{mg} \mathrm{mL}^{-1} \min ^{-1}$ (figure not shown). The low $K_{m}$ value of BGP indicated that the enzyme could easily react with the substrate with a high rate of hydrolysis.

\subsubsection{Storage Stability of BGP}

The dried BGP showed high stability at low temperature $\left(-20^{\circ} \mathrm{C}\right)$, but $46 \%$ of the activity was lost after 90 days at $4 \pm 1{ }^{\circ} \mathrm{C}$ and drastically lost its proteolytic activity when stored at room temperature (Table 3). The half-life, $\mathrm{t}_{1 / 2}$, of BGP increased from 3 days at room temperature to 3.5 months at $4 \pm 1{ }^{\circ} \mathrm{C}$ and 22 months at $-20{ }^{\circ} \mathrm{C}$. The $\mathrm{t}_{1 / 2}$ of this enzyme kept at $-20^{\circ} \mathrm{C}$ was higher than that of ginger protease extracted using acetone precipitation which has a $t_{1 / 2}$ of 18 months [8]. However it lower than that of common ginger protease which has $\mathrm{t}_{1 / 2}$ of 24.5 months (data not shown). 
Table 3. Effect of storage temperature on activity of bentong ginger protease.

\begin{tabular}{cccc}
\hline \multirow{2}{*}{ Time (day) } & \multicolumn{3}{c}{ Relative Activity (\%) at Different Storage Temperature } \\
\cline { 2 - 4 } & $\mathbf{R T} *$ & $\mathbf{4} \pm \mathbf{1}{ }^{\circ} \mathbf{C}$ & $\mathbf{- 2 0} \pm{ }^{\circ} \mathbf{C}$ \\
\hline 0 & $100.0 \pm 0.0$ & $100.0 \pm 0.0$ & $100.0 \pm 0.0$ \\
1 & $67.7 \pm 1.1$ & $87.1 \pm 0.4$ & $99.3 \pm 0.1$ \\
2 & $47.1 \pm 1.1$ & $85.3 \pm 0.2$ & $98.5 \pm 0.1$ \\
3 & $52.7 \pm 0.7$ & $83.2 \pm 0.1$ & $98.5 \pm 0.1$ \\
4 & $37.0 \pm 1.1$ & $81.8 \pm 0.7$ & $98.1 \pm 0.3$ \\
5 & $22.7 \pm 2.3$ & $78.8 \pm 0.2$ & $97.6 \pm 0.3$ \\
10 & $16.3 \pm 2.1$ & $76.6 \pm 0.3$ & $96.9 \pm 0.3$ \\
20 & $12.9 \pm 2.3$ & $74.0 \pm 0.7$ & $95.2 \pm 0.1$ \\
30 & $9.9 \pm 2.3$ & $66.6 \pm 0.2$ & $94.4 \pm 0.4$ \\
60 & $8.2 \pm 3.3$ & $62.1 \pm 0.3$ & $93.2 \pm 0.4$ \\
90 & $3.4 \pm 1.9$ & $56.1 \pm 0.8$ & $93.6 \pm 0.2$ \\
\hline \multicolumn{4}{c}{ RT (room temperature). }
\end{tabular}

\section{Experimental Section}

\subsection{Materials and Methods}

Ginger rhizomes (Bentong variety) of commercial maturity were purchased from wet markets in Sri Kembangan, Malaysia. The ginger plants were grown in a highland area located about 700 meters above sea level. Three different batches of the ginger were used. Azocasein, cysteine, ethylenediamine tetra acetic acid (EDTA) and ascorbic acid were purchased from Sigma-Aldrich, (St. Louis, MO, USA). Other chemicals used in this experiment were of analytical grade.

\subsection{Extraction of Bentong Ginger Protease (BGP)}

The ginger rhizomes were first cleaned under running tap water and dried in the sun for $24 \mathrm{~h}$ prior to extraction. They were then finely chopped and $100 \mathrm{~g}$ were homogenized with $200 \mathrm{~mL}$ of $100 \mathrm{mM}$ pottasium phosphate buffer using a Waring blender (New Hartford, CT, USA). The homogenate was then filtered through a piece of cheesecloth following which the filtrate was centrifuged at $10,500 \times g$ (Sartorius AG, Gottingen, Germany) and $4{ }^{\circ} \mathrm{C}$ for $30 \mathrm{~min}$. The proteolytic activity of the supernatant was immediately determined as described in Section 3.5.

\subsection{Effect of $p H$ on Extraction of $B G P$}

To test the effect of extraction $\mathrm{pH}$, a series of buffers was used in the standard extraction procedure described above. Ginger rhizome (100 g) was washed, cut into fine pieces and homogenized separately with $100 \mathrm{mM}$ potassium phosphate buffer $(200 \mathrm{~mL}, \mathrm{pH}$ 6.4, 6.8, 7.0 and 7.2) and $100 \mathrm{mM}$ Tris- $\mathrm{HCl}$ buffer $(200 \mathrm{~mL}, \mathrm{pH} 7.6,8.0,8.4$, and 8.8). The resulting homogenates were filtered through a piece of cheesecloth and the filtrates were centrifuged at $10,500 \times \mathrm{g}$ and $4{ }^{\circ} \mathrm{C}$ for $30 \mathrm{~min}$. The supernatants were then assayed for proteolytic activity. The optimum extraction $\mathrm{pH}$ was chosen based on its performance on producing BGP with highest relative protease activity. 


\subsection{Effect of Stabilizers on Extraction of Ginger Protease}

To test the effect of stabilizers, three additives were examined for their ability to protect the activity of ginger protease during extraction. Based on the standard extraction procedure, ginger rhizomes (100 g) were washed, cut into fine pieces and homogenized with $100 \mathrm{mM}$ potassium phosphate buffer $(200 \mathrm{~mL}$, $\mathrm{pH}$ 7.0) containing either of the following stabilizers: $0.2 \%$ ascorbic acid, $0.2 \%$ ascorbic acid and $5 \mathrm{mM}$ EDTA, or $10 \mathrm{mM}$ cysteine and $5 \mathrm{mM}$ EDTA. After filtration and centrifugation, the proteolytic activity of the supernatant was measured and compared with control (without any stabilizers) to determine the most effective stabilizer. The control was extract (supernatant) without the addition of any stabilizer.

\subsection{Proteolytic Activity Assay}

A colorimetric method adopted from Adulyatham and Owusu-Apenten [8] was used to measure the activity of BGP with a slight modification. The substrate azocasein $(1 \mathrm{mg} / \mathrm{mL})$ was prepared in $100 \mathrm{mM}$ potassium phosphate buffer $(\mathrm{pH} \mathrm{7})$ prior to the analysis. One milliliter of azocasein solution was pipetted into a $2 \mathrm{~mL}$ Eppendorf tube containing buffer solution $(0.6 \mathrm{~mL})$ and enzyme extract (supernatant, $0.1 \mathrm{~mL}$ ) to initiate the reaction. After mixing, the reaction mixture was incubated for $20 \mathrm{~min}$ at $60{ }^{\circ} \mathrm{C}$. The reaction was terminated with the addition of trichloroacetic acid (TCA, $0.3 \mathrm{~mL}$, $10 \% \mathrm{w} / \mathrm{v}$ ) solution, followed by centrifugation at $9,000 \times \mathrm{g}$ at room temperature for $10 \mathrm{~min}$ (Sartorius Model 3-18 k, Sartorius AG, Weender Land Strasse, Gottingen, Germany). The absorbance of the supernatant was then measured at $410 \mathrm{~nm}$. A blank was prepared as above except that the enzyme was first heated in a boiling water bath for $5 \mathrm{~min}$. One unit (U) of protease activity was defined as the amount of the enzyme that cause an increase in absorbance by 1 absorbance unit per $\mathrm{mL}$ extract per minute. Specific activity is expressed as $\mathrm{U} / \mathrm{mg}$ protein.

\subsection{Protein Concentration Determination}

Protein content of the crude extract and dried BGP was determined using Lowry method [27] using bovine serum albumin (Sigma Chemical Co., St. Louis, MO, USA) as standard. The protein content was expressed as $\mathrm{mg} / \mathrm{mL}$ for crude extract.

\subsection{Production of BGP Powder}

To produce dried BGP, a total of $100 \mathrm{~g}$ of ginger rhizome was used. The enzyme was first extracted from the rhizome as described above using $100 \mathrm{mM}$ potassium phosphate buffer $(200 \mathrm{~mL}, \mathrm{pH} 7.0)$ containing $10 \mathrm{mM}$ cysteine and $5 \mathrm{mM}$ EDTA. After centrifugation at 10,500 $\times \mathrm{g}$ (Sartorius Model 3-18 k, Sartorius AG) and $4{ }^{\circ} \mathrm{C}$ for $30 \mathrm{~min}$, the supernatant was filtered through Celite (diatomaceous earth) to remove any suspended materials and then mixed with $60 \%$ ammonium sulfate to partially concentrate and purify the enzyme. The precipitate that was obtained was collected by centrifugation at $10,500 \times g$ and $4{ }^{\circ} \mathrm{C}$ for $30 \mathrm{~min}$ and then resolubilized in a minimal volume of $50 \mathrm{mM}$ potassium phosphate buffer ( $\mathrm{pH}$ 7.0). The enzyme solution was dialyzed against two changes of $50 \mathrm{mM}$ potassium phosphate buffer (pH 7.0) containing $1 \mathrm{mM}$ EDTA for $16 \mathrm{~h}$ at $4{ }^{\circ} \mathrm{C}$. The dialysate was centrifuged at $10,500 \times g$ and $4{ }^{\circ} \mathrm{C}$ for $20 \mathrm{~min}$ to remove any insoluble substances and then lyophilized using a freeze dryer 
(Model-7753032 Freeze Dry System, Labconco, Kansas City, MO, USA). The yield of dried BGP was determined gravimetrically while the proteolytic activity was measured as described above using a $1.0 \mathrm{mg}$ dried $\mathrm{BGP} / \mathrm{mL}$ solution. The BGP was then stored at $-20{ }^{\circ} \mathrm{C}$ prior to further analysis. The production of BGP powder was conducted in triplicate.

\subsection{Characterization of Bentong Ginger Protease}

\subsubsection{Determination of Protease Type}

Four different protease inhibitors were used to classify the type of Bentong ginger protease under study. Ten millimolar solutions of $o$-phenanthroline, phenylmethylsulfonyl fluoride (PMSF), EDTA and $N$-ethylmaleimide (NEM) in $100 \mathrm{mM}$ potassium phosphate buffer (pH 7.0) were prepared prior to the analysis. The activity of $1.0 \mathrm{~mL}$ of BGP solution $(1.0 \mathrm{mg} / \mathrm{mL}$ dried BGP) pre-incubated with $1.0 \mathrm{~mL}$ of each inhibitor solution for $1 \mathrm{~h}$ at $25{ }^{\circ} \mathrm{C}$ was determined using the standard proteolytic method as described above. The activity obtained is expressed as relative activity based on the percentage of proteolytic activity of inhibitor-treated enzyme against the control (without added inhibitor). The protease type of BGP was determined based on the degree of inhibitory effect.

\subsubsection{Optimum Temperature}

Determination of the optimum temperature of BGP was conducted by assaying the enzyme activity at various temperatures. The enzyme solution $(1.0 \mathrm{mg} / \mathrm{mL}$ dried BGP solubilized in $100 \mathrm{mM}$ potassium phosphate buffer, $\mathrm{pH}$ 7.0) was prepared prior to analysis. Its activity was then assayed at temperatures ranging from 20 to $90{ }^{\circ} \mathrm{C}$ using $1 \mathrm{mg} / \mathrm{mL}$ azocasein as the substrate for $20 \mathrm{~min}$ using the proteolytic assay as described above.

\subsubsection{Optimum $\mathrm{pH}$}

The optimum $\mathrm{pH}$ of BGP was determined by measuring the activity of the enzyme at different $\mathrm{pH}$ values ranging from $\mathrm{pH} 3$ to 10 . The buffers used were as follows: $100 \mathrm{mM}$ citrate buffer ( $\mathrm{pH} 3.0-5.0$ ), $100 \mathrm{mM}$ potassium phosphate buffer (pH 6.0 and 7.0), $100 \mathrm{mM}$ Tris-HCl buffer ( $\mathrm{pH} 8.0$ and 9.0) and $100 \mathrm{mM}$ sodium carbonate buffer ( $\mathrm{pH} \mathrm{10)}$. Azocasein was dissolved in the respective buffers to obtain $1 \mathrm{mg} / \mathrm{mL}$ solutions and then used to assay the activity of a solution of $1 \mathrm{mg} / \mathrm{mL}$ of dried BGP. The method of proteolytic assay was as described above.

\subsubsection{Effect of Cations and Detergents}

The effect of cations on activity of BGP was determined by including $0.1 \mathrm{~mL}$ of $10 \mathrm{mM}$ cation $\left(\mathrm{K}^{+}\right.$, $\mathrm{Na}^{+}, \mathrm{Li}^{+}, \mathrm{Mg}^{2+}, \mathrm{Ca}^{2+}, \mathrm{Ba}^{2+}, \mathrm{Co}^{2+}, \mathrm{Zn}^{2+}, \mathrm{Cu}^{2+}, \mathrm{Hg}^{+}$and $\mathrm{Al}^{3+}$ ) solutions which were prepared from their chloride salts in separate proteolytic assay reaction mixtures. BGP solution containing $1.0 \mathrm{mg} / \mathrm{mL}$ of dried BGP was prepared prior to the proteolytic activity analysis as described above. The effect of detergents in the activity of BGP was tested by adding $0.1 \mathrm{~mL}$ of $5 \mathrm{mM}$ (to give a final concentration of $0.25 \mathrm{mM}$ ) of EDTA, Triton X-100, sodium dodecyl sulfate (SDS), Tween 20 or Tween 80 into 
separate reaction mixture. The activity obtained is expressed as relative activity based on the percentage of proteolytic activity of treated enzyme against the control (without added cation/detergent).

\subsubsection{Determination of $\mathrm{K}_{\mathrm{m}}$ and $\mathrm{V}_{\max }$}

The $K_{m}$ and $\mathrm{V}_{\max }$ BGP were determined using azocasein as a substrate at selected optimum temperatures for $10 \mathrm{~min}$ based on the assay method described above. One $\mathrm{mg} / \mathrm{mL}$ of BGP was prepared prior to the analysis and the concentrations of substrate used in this study were $0.1,0.5,1,1.5$ and $2.0 \mathrm{mg} / \mathrm{mL}$. The $K_{m}$ and $\mathrm{V}_{\max }$ were calculated as described by Lineweaver-Burk [28].

\subsubsection{Storage Stability}

To determine the storage stability, BGP ( $1 \mathrm{mg})$ was placed in an Eppendorf and stored at $-20{ }^{\circ} \mathrm{C}$; $4 \pm 1{ }^{\circ} \mathrm{C}$ and room temperature for up to 90 days. The BGP was then dissolved in $100 \mathrm{mM}$ potassium phosphate buffer $(1 \mathrm{~mL})$ prior to the analysis. The activity obtained was expressed as relative activity as described above. The half-life $\left(\mathrm{t}_{1 / 2}\right)$ of the BGP was calculated by fitting the data of natural $\log (\ln )$ activity versus time (day) [8].

\subsection{Statistical Analysis}

The experiments were conducted in triplicate. The data which were presented as mean \pm standard deviation was analyzed using Analysis of Variance (ANOVA) with Minitab 14 (State College, PA USA, 2003) statistical software.

\section{Conclusions}

The protease extracted from ginger rhizome var. Bentong by $\mathrm{pH} 7$ phosphate was classified as a cysteine protease showing optimum activity at high temperature of $60{ }^{\circ} \mathrm{C}$ and over a wide range of $\mathrm{pH}$ values from 6 to 8 . The enzyme could react with substrate with a higher rate of hydrolysis and demonstrated high storage stability at low temperatures. The properties of BGP obtained in this study should facilitate its application in the food and other industries.

\section{Acknowledgments}

The authors are grateful for the financial support from the Government of Malaysia awarded to H. M. Ghazali.

\section{Author Contributions}

Ahmad Nafi' and Hasanah M. Ghazali are the main contributor of this paper. Hasanah M. Ghazali is also supervisor of Ahmad Nafi', while Foo Hooi Ling and Jamilah Bakar are the co-supervisor.

\section{Conflicts of Interest}

The authors declare no conflict of interest. 


\section{References}

1. Ravindran, P.N.; Babu, N.B. Ginger: The Genus Zingiber; CRC Press: New York, NY, USA, 2005; pp. 1-15.

2. Ghasemzadeh, A.; Jaafar, H.Z.; Rahmat, A. Antioxidant activities, total phenolics and flavonoids content in two varieties of Malaysia young ginger (Zingiber. officinale Roscoe). Molecules 2010, 12, 4324-4333.

3. Surh, Y.J. Cancer chemoprevention with dietary phytochemical. Nat. Rev. Can. 2003, 3, 768-780.

4. Jose, S. Industrial enzymes: A global strategic business report. Available online: http://www.prweb.com/releases/industrial_enzymes/proteases_carbohydrases/prweb8121185.htm (accessed on 2 July 2014).

5. Rathina, R.K.; Mahendrakar, N.S. Effect of ensiling and organic solvents treatment on proteolytic enzymes of layer chicken intestine. J. Food Sci. Technol. 2010, 47, 320-324.

6. Su, H.P.; Huang, M.J.; Wang, H.T. Characterization of ginger proteases and their potential as a rennin replacement. J. Sci. Food Agric. 2009, 89, 1178-1185.

7. Ravikumar, G.; Gomathi, D.; Kalaiselvi, M.; Uma, C. A protease from the medicinal mushroom Pleurotus. sajor-caju; production, purification and partial characterization. Asian Pac. J. Trop. Biomed. 2012, 2, S411-S417.

8. Adulyatham, P., Owusu-Apenten, R. Stabilization and partial purification of a protease from ginger rhizome (Zingiber. officinale Roscoe). J. Food Sci. 2005, 70, 231-234.

9. Thompson, E.H.; Wolf, I.D.; Allen, C.E. Ginger rhizome: A new source of proteolytic enzyme. J. Food Sci. 1973, 38, 652-655.

10. Choi, K.H.; Laursen, R.A. Amino-acid sequence and glycan structures of cysteine protease with proline specifity from ginger rhizome (Zingiber. officinale). Eur. J. Biochem. 2000, 267, 1516-1526.

11. Bhaskar, N.; Sachindra, N.; Modi, V.; Sakhare, P.; Mahendrakar, N. Preparation of proteolytic activity rich ginger powder and evaluation of its tenderizing effect on spent-hen muscles. J. Musc. Food 2006, 17, 174-184.

12. Kim, M.; Hamilton, S.E.; Guddat, L.W.; Overall, C.M. Plant collagenase: Unique collagenolytic activity of cysteine proteases from ginger. Bba-Gen. Subjects 2007, 1770, 1627-1635.

13. Nafi, A.; Foo, H.L.; Jamilah, B.; Ghazali, H.M. Properties of proteolytic enzyme from ginger (Zingiber officinale Roscoe). Int. Food Res. J. 2013, 20, 2133-2138.

14. Factfish. Malaysia: Ginger, production quantity (tons). Available online: http://www.factfish.com/ statistic-country/malaysia/ginger,+production+quantity (accessed on 2 July 2014).

15. Suhaimi, M.Y.; Mohamad, A.M.; Mahamud, S.; Khadzir, D. Effects of substrates on growth and yield of ginger cultivated using soilless culture. J. Trop. Agric. Fd. Sc 2012, 40,159-168.

16. Ghasemzadeh, A.; Jaafar, H.Z.E.; Rahmat, A. Elevated carbon dioxide increases contents of flavonoids and phenolic compounds, and antioxidant activities in Malaysian young ginger (Zingiber officinale Roscoe.) varieties. Molecules 2010, 15, 7907-7922.

17. Ghasemzadeh, A.; Jaafar, H.Z.E. Interactive effect of salicylic acid on some physiological features and antioxidant enzymes activity in ginger (Zingiber officinale Roscoe). Molecules 2013, $18,5965-5979$. 
18. Aluko, R.E. The extraction and purification of proteins: An introduction. In Proteins in Food Processing, 1st ed.; Yada, R.Y., Ed.; CRC Press: Boca Raton, FL, USA, 2004; pp. 323-351.

19. Qiao, Y.; Tong, J.; Wei, S.; Du, X.; Tang, X. Computer and computing technologies in agriculture II; In IFIP International Federation for Information Processing; Li, D., Chunjiang, Z., Eds.; Springer: Boston, MA, USA, 2009; pp. 1619-1628.

20. Parisi, M.; Morena, S.; Fernandez, G. Characterization of a novel cysteine peptidase from tissue culture of garlic (Allium sativum L.). In Vitro Cell. Dev. Biol.-Plant 2002, 38, 608-612.

21. Demir, Y.; Güngör, A.; Duran, E.D.; Demir, N. Cysteine protease (capparin) from capsules of caper (Capparis spinosa). Food Technol. Biotechnol. 2008, 46, 286-291.

22. Frey, P.A.; Hegeman A.D. Enzymatic Reaction Mechanisms. Oxford University Press, Inc.: New York, NY, USA, 2007; pp. 297-332.

23. Huang, X.W.; Chen, L.J.; Luo, Y.B.; Guo, H.Y.; Ren, F.Z. Purification, characterization, and milk coagulating properties of ginger proteases. J. Dairy Sci. 2011, 94, 2259-2269.

24. Dubey, V.K.; Jagannadham, M.V. Procerain, a stable cysteine protease from the latex of Calotropis procera. Phytochemistry 2003, 62, 1057-1071.

25. Mehrnoush, A.; Mustafa, S.; Sarker, M.Z.I.; Yazid, A.M.M. Optimization of the conditions for extraction of serine protease from kesinai plant (Streblus. asper) leaves using response surface methodology. Molecules 2011, 16, 9245-9260.

26. Voet, D.; Voet, J.G. Biochemistry, 4th ed.; John Wiley \& Sons, Inc.: New York, NY, USA, 2011; pp. 129-162.

27. Lowry, O.H.; Rosenbrough, N.J.; Farr, A.L.; Randall, R.J. Protein measurenment with the Folin phenol reagent. J. Biol. Chem. 1951, 193, 265-275.

28. Lineweaver, H.; Burk, D. The determination of enzyme dissociation constants. J. Am. Chem. Soc. 1934, 56, 658-666.

Sample Availability: Samples of the compounds Bentong ginger are available from the authors.

(C) 2014 by the authors; licensee MDPI, Basel, Switzerland. This article is an open access article distributed under the terms and conditions of the Creative Commons Attribution license (http://creativecommons.org/licenses/by/3.0/). 